\title{
Establishment of Policy Support System for College Students' Entrepreneurship in Suzhou
}

\author{
http://dx.doi.org/10.3991/ijet.v8i5.2995 \\ X.Y. Tian \\ Suzhou University of Science and Technology, Suzhou, China
}

\begin{abstract}
The college students' entrepreneurship is of great significance to the personal growth and social development. Firstly, the situations and problems of college students who start their own business are presented by questionnaire survey. Secondly, measures and defects of the policy are explained. Finally, a policy support system for the college students' entrepreneurship is constructed based on business cycle consisting of training, financing, supporting facilities, implementation, environmental evaluation and identification evaluation, thus providing references for the government to promote the college students' entrepreneurship.
\end{abstract}

Index Terms - college students' entrepreneurship, situation, business cycle, entrepreneurship policy

\section{INTRODUCTION}

The business start-up boom has not only become an active phenomenon in social and economic life, but also a driving force for sustained and rapid development of economy [1]. It is of great significance in guaranteeing social and economic stability through encouraging and promoting personal business, alleviating employment pressure and solving the employment contradictions. "We are facing a silent revolution-the one in which the innovation and entrepreneurial spirit of human will win a great victory. I think the entrepreneurial revolution in the $21 \mathrm{st}$ century will have a far-reaching influence even beyond the industrial revolution in the 19th century and 20th century" [2], said by Professor Timmons, as the pioneer in education and study of entrepreneurship from American.

In the past thirty years, the economic globalization and the coming of the Knowledge Economy have provided a good opportunity for starting a business, and the entrepreneurial activity has become an important part in the current economic development. In China, along with the increasing university enrollment in the resent successive years, the college students are facing much employment pressure. More and more graduates choose to start their own businesses. However, more and more problems are emerging in the entrepreneurial activities, which have attracted wide attention in society. Business policy is of much importance for entrepreneurs. A scientific, objective and reasonable business policy is the precondition of venture success. In order to truly ease college students' employment pressure, to solve the problems in the business start-up, to ensure the harmonious and sustainable development and to maintain social stability, Suzhou city government issued a series of supporting policies based on the national college students' venture policy framework in 2010, which relieved the employment stress to a certain extent. However, those policies are not really implement- ed and fail to solve the problems in business. The business policy system is not perfectly constructed, which leads to an obstacle to the university students' business. Therefore, that how to establish a policy support system and promote the implementation of the policies is in much urgency.

\section{The Situations And Problems of College STUDENTS' ENTREPRENEURSHIP IN SUZHOU}

Table 1 shows the graduation employment situation according to the statistics from the Graduate Career Center of Suzhou [3].Table 1 shows the college graduates overall business start-up status in Suzhou, but lacks of specific description on entrepreneurial enterprises and supporting policies. The data obtained has its limitations due to the research time, target and site. Given the above, the college students in the University Science Park of Suzhou are selected as the respondents to the business situation. A total of 107 questionnaires are handed out and 98 copies are taken back, of which 84 are effective with recovery ratio as $78.5 \%$. This research aims to interpret the present situation of college students' entrepreneurship based on the statistical feedback, and tries to conclude the commonly existing problems in the business start-up, thus putting forward suggestions with policy.

TABLE I.

THE GRADUATE JOB INFORMATION OF SUZHOU

\begin{tabular}{|c|c|c|c|c|}
\hline Item & $\begin{array}{c}\text { Num- } \\
\text { ber of } \\
\text { prac- } \\
\text { tice } \\
\text { bases }\end{array}$ & $\begin{array}{c}\text { Num- } \\
\text { ber of } \\
\text { trainees }\end{array}$ & $\begin{array}{c}\text { Number of } \\
\text { entrepre- } \\
\text { neurship } \\
\text { bases }\end{array}$ & $\begin{array}{c}\text { Number } \\
\text { of en- } \\
\text { trepre- } \\
\text { neurs }\end{array}$ \\
\hline The whole city & 697 & 1260 & 129 & 622 \\
\hline Town & 26 & 100 & -- & -- \\
\hline Zhangjiagang & 68 & 2 & 19 & 0 \\
\hline Changshu & 60 & 147 & 9 & 21 \\
\hline Taicang & 255 & 358 & 7 & 308 \\
\hline Kunshan & 144 & 485 & 30 & 19 \\
\hline Wujiang & 11 & 0 & 15 & 0 \\
\hline Wuzhong & 27 & 0 & 1 & 0 \\
\hline Xiangcheng & 34 & 10 & 7 & 0 \\
\hline Pingjiang & 13 & 93 & 14 & 0 \\
\hline Canglang & 14 & 56 & 14 & 273 \\
\hline Jinchang & 7 & 0 & 9 & 1 \\
\hline Industrial park & 17 & 9 & 8 & 0 \\
\hline High - tech & 21 & 0 & 6 & 0 \\
\hline zone & & & & \\
\hline
\end{tabular}




\section{A. The Characteristics of Enterprises}

Concentrated industries and related to professions: The 84 respondents start their businesses in diverse industries, which yet tend to be concentrated. Those engaged in IT industry account for $35.7 \%$ and those in environment and new materials for $14.2 \%$, Biotechnology for $14.2 \%$, Management Consulting for $28.6 \%$, and retail for $7.1 \%$ (see figure 1). Meanwhile, the industries tried by the students are highly related to their professions with correlation as $71 \%$ and the rest $29 \%$ of students engaged in industries irrelevant with their professions.

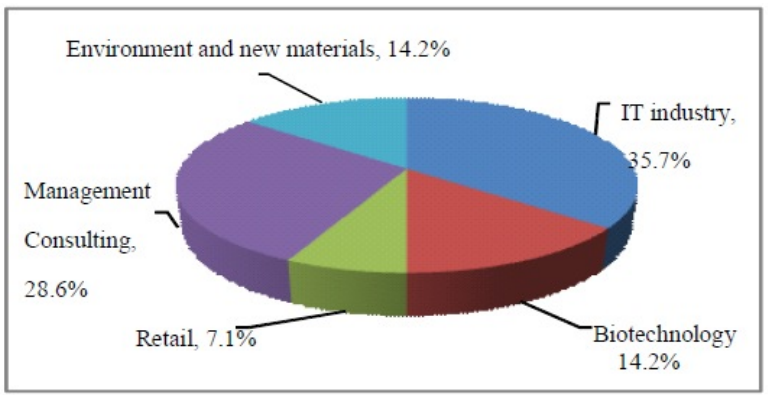

Figure 1. Field of entrepreneurship activities

Enterprises with small scale and poor operating conditions: $92.85 \%$ of those respondents who have started their business have small company with less 20 employees, and $50 \%$ have less 5 employees, which indicate that the company scale is comparatively small. It can yet be regarded as wise to be a small company with low risk and easy operation and management due to the long and difficult business road and the limited capital.

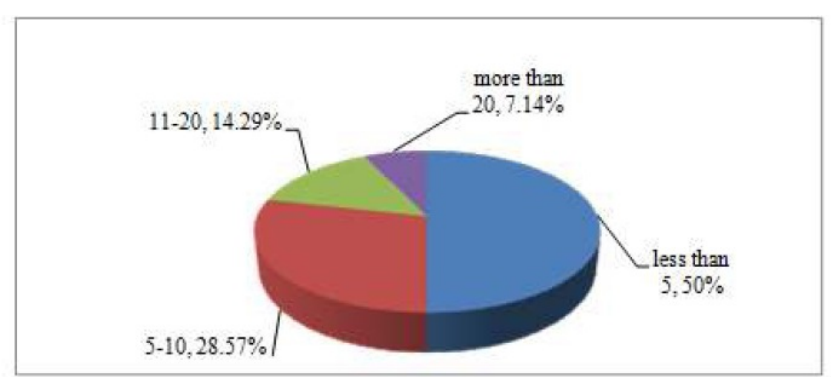

Figure 2. Entrepreneurship enterprise scale

At present, the college students' entrepreneurship activities are not very optimistic, of which few succeed in the first time. The World Entrepreneurship Lab survey in 2006 shows that China's overall entrepreneurial success rate has reached $30 \%$ and college students' business success rate is only $2 \%-3 \%$, which accounts for ten percent of the successful enterprises [4]. This survey also shows that only $21.43 \%$ of the college students' companies "operating in good condition and with healthy development", $35.71 \%$ of the companies can achieve "balanced and smooth operation", while $28.57 \%$ of companies" is considering to change projects or stop business", $14.29 \%$ had stopped operation, as shown in figure 3 . Nearly $60 \%$ of college students are not satisfied or even worried about their own businesses.

Enterprises with low profit: Figure 4 shows that the overall profit of the enterprises started by graduates is barely satisfactory. $64.3 \%$ of the enterprises' profit accounts for one hundred thousand or less, which is partly due to the short time as less than one year. Enterprises with profit between one hundred and ten thousand and twenty hundred accounts for more than $28.6 \%$, the profit between two hundred thousand and five hundred thousand is only $7.1 \%$, while no enterprises can create more than five hundred thousand.

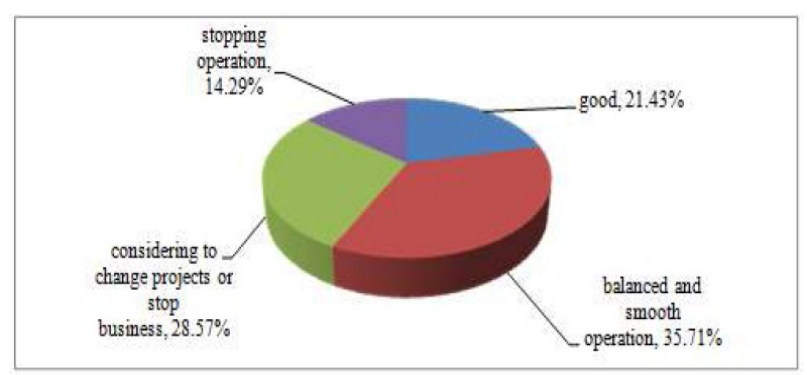

Figure 3. Operating conditions of entrepreneurship enterprise

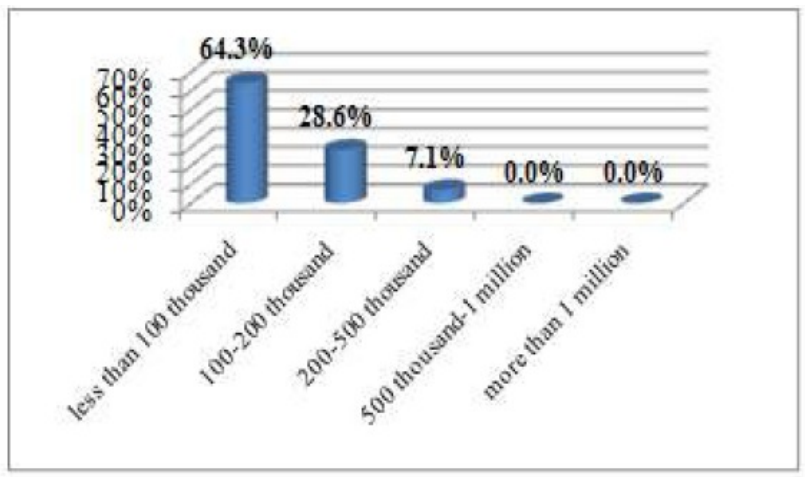

Figure 4. Overall profit of the enterprises

\section{B. Business Support}

Single source of funds and difficulty in financing: The college students entrepreneurial survey of 84 respondents concludes that $50 \%$ of the venture capital come from personal savings of team members, $28.6 \%$ is supported by family or friends, $14.2 \%$ is lend from bank loans, only $7.1 \%$ is financed by school or government venture fund. No enterprises obtain start-up capital from venture investment channels.

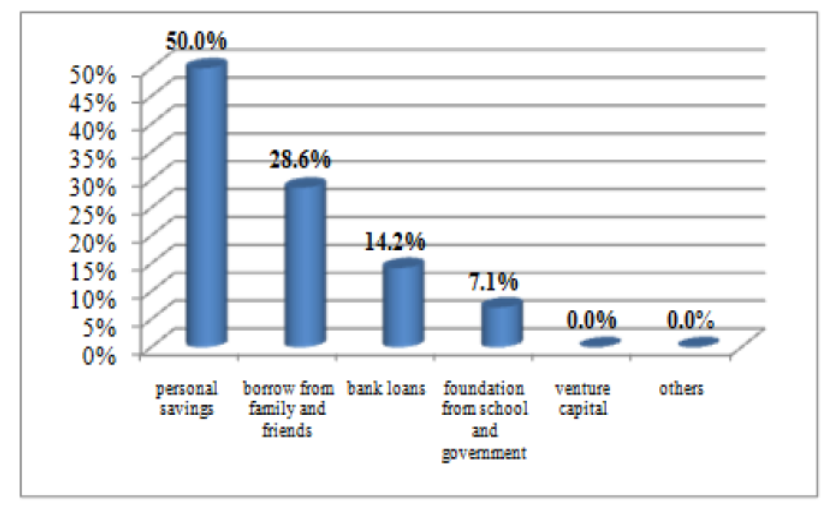

Figure 5. Entrepreneurial start-up capital source

Entrepreneurs generally regard funds as a very important role in the business start-up. Yet at present, college students have less access to finance [5]. $42.9 \%$ of the respondents think it very difficult to raise money and $28.6 \%$ think it comparatively difficult, both of which account for 
more than $71.5 \%$. Only less than twenty percent of the respondents think it easier to find venture capital.

Function of knowledge and skill: Fifty percent of the 84 entrepreneurs surveyed think school education on entrepreneurship is of great importance to their business. Other thirty percent think it comparatively important and play a part in their business. The data indicates that entrepreneurship education is of significance to cultivate business knowledge and skill and innovative spirit.

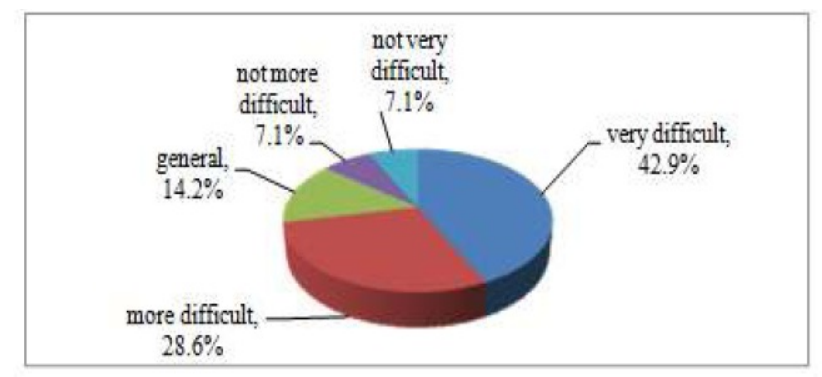

Figure 6. Degree of difficulty of entrepreneurial financing

The survey also shows that $39.7 \%$ of entrepreneurs obtain business knowledge and skills through social practice, $24.6 \%$ of entrepreneurs through the entrepreneurial education and training, and $19.9 \%$ think that sharing experience and attending professional knowledge training and lecture are also important accesses to business knowledge and skills. Apart from that, 15.8\% get information through books, network, business practice and part-time jobs. These data can provide reference to the college entrepreneurship education [6].

Policy support is in urgent need: The survey indicates that $34 \%$ of the college students think the business startup very hard if there is no policy support. And another $34 \%$ think it comparatively hard. It can be seen that the policy support is of very importance to the survival and success of the businesses.

All the participants in this survey hold the view that policy plays an important part in the business start-up in terms of tax benefit and licensing procedure. $85 \%$ of the college students believe that tax benefit is of much importance, which is determined by the economic weakness of those enterprises. Meanwhile, nearly $60 \%$ of college students take the simplification of licensing as very important, which will help mobilize the enthusiasm for entrepreneurship.

\section{Measures AND Defects of The Policy For COLlEGE STUdENTS' Business START-UP IN SUZHOU}

Suggestions on the Implementation of Employment Promotion for the Graduates is officially issued by the Human Resources and Social Security Bureau, the Bureau of Education, the Bureau of Finance, Suzhou branch of Central Bank, the national tax bureau, the local tax bereau and the municipal Bureau of Industry and Commerce on September 29, 2010, aiming to establish" five mechanisms " and to promote the employment of college graduates and putting forward the specific requirements as follows [7]: establishing the supply and demand mechanism to implement the "post development plan"; expanding employment by encouraging business startups to implement the "entrepreneurial driven plan"; establishing employment assistance mechanism to implement the "employment service and aid plan"; establishing employment skills upgrading mechanism to implement the "employment practice and professional skills training plan"; establishing a unified and standard employment management and assessment mechanism to implement a college graduates employment management network of four levels.

Moreover, the Employment Service Center of the $\mathrm{Hu}$ man Resources and Social Security Bureau of Suzhou city put forward four policies and two measures to booster college graduates entrepreneurship, including providing free training to upgrade their ability, securing small loans to expand financing channels, providing social security such as entrepreneurship training subsidy, encouraging entrepreneurial behavior by providing business subsidy. Those college graduates who were born in Suzhou and have no working experiences, also participate in the entrepreneurship training and start their business for the first time, also pay social insurance and tax will get the entrepreneurship subsidy as two thousand yuan[7]. Since the implementation of the policy, there has been 35 college graduates enjoying this subsidy with the amount of seventy thousand Yuan. For college graduates as a special business group, they lack of the real business environment and social practice. Therefore, the measures to build "college student's business start-up camp" and "college students entrepreneurial training" have become the first step for college graduates entrepreneurship practice.

In addition, Suzhou constructed a public entrepreneurship training base (entrepreneurship nursery) for college students, which covers a total area of 815 square meters and a total of fifty nurseries [7] with its function of business incubation, business training and entrepreneurial demonstration for college students and entrepreneur teams. At present, the projects set up in this base mainly cover the fields of electronic information, business trade, management consulting and cultural ideas and businesses and up to the end of August 2011, it has attracted 35 businesses. Entrepreneurship training base (entrepreneurship nursery) plays an important role to promote college students' venture businesses.

Compared with other cities and regions, the supporting policies for college students business in Suzhou come late with only more than one year. Most of the policy supporting measures has not issued and is still need to be researched and improved. Generally speaking, the existing policies have the defects as follows.

\section{A. Policies Need to Be Fully Implemented and Advocated}

College graduates who participate in entrepreneurship training and get the certificate or have the business licenses for self-management entity business license and a loan application can apply for small secured loans. The loan is divided into two levels, the municipal and the district level, with credit lines of $¥ 50-100$ thousand and $¥$ $30-50$ thousand respectively, and period of two years. However, some authorities did not issue specific implementations and did not release them to the public. It should be mentioned that the college students have not fully recognize these policies due to the lack of publication. We designed the questionnaire for the level of understanding of the entrepreneurship policy and found that many graduates have no access to the policies with $71 \%$ of students having no knowledge, $23 \%$ of the students 
having a better understanding and, only $7 \%$ of the students understanding very well. The survey above not only indicates the invalid publication and also implies the incomplete implementation of the policies with no real benefit to entrepreneurs.

\section{B. Lack of Targeted and Systematic Entrepreneurial Supporting Policies}

According to investigation, the local government has introduced relevant preferential policies and promoting measures to assist the college students' business start-up, but lack of strong measures for publication, execution and implementation. Those policies nearly end up on the shelf due to their lack of incomplete system and insufficient coordination and difficulties in forming a cohesive force, thus are not able to bring practical support and help to students who will start their own business. The conclusion above is easily drawn in this survey in which $71.4 \%$ expressed their dissatisfaction and only less than $10 \%$ of the students expressed their great satisfaction.

\section{Single Funding Channel for Business}

Apart from the national loan, college students in Suzhou are facing difficulties in financing for business. Most funds are from personal savings and family support but the premise is that you are rich or you have a rich family. However, most graduates have no savings, and those from poor families can hardly get support for their entrepreneurship activities. The funds from their friends are also very limited as which ultimately from personal savings and families. Most venture capitals are reluctant to offer a favor as they consider the high investment risk and low recovery rate of those business tried by graduates. Moreover, there is a lack of a comprehensive risk investment mechanism.

\section{ESTABLISHMENT OF POLICY SUPPORT SySTEM BASED ON THE ENTREPRENEURIAL CYCLE}

College graduates are valuable human resources of the country. Proper guidance and support for college student's business start-ups can not only broaden the way for scientific and technological achievements, but also help to improve the success rate of entrepreneurship, thus play a role in the maintenance of social stability, promoting the economic structural adjustment, increasing economic development and creating a good atmosphere of respecting and supporting entrepreneurship. The supporting policies for college students business in Suzhou come late and are incomplete in term of financing, guidance, motivation and evaluation. As a systemic project, business start-ups need support from different authorities in different periods. Therefore, a policy support system for entrepreneurship based on the entrepreneurial cycle as early, middle and late periods is constructed in this paper.

\section{A. Early Stages}

Students will encounter many problems in their first try of business as they are inexperienced. For example, many college students' entrepreneurs do not understand the registered procedures for enterprises. The government can open a free training course which can be divided into four stages. First is counseling before business which helps college students understand the business environment, relevant policies and application procedures to stimulate their confidence and determination for entre- preneurship. The second stage is the study of the theory of entrepreneurship, including the courses of business management, sales management and finance and accounting. The third stage assists them to solve difficulties and blind spots in business operations. The fourth stage is the tracking counseling which helps college students sum up experiences and absorb lessons to prepare for the better and stronger development.

Government is expected to relieve tax pressure of startups. Special funds are supposed to be built up which can be classified by "seed fund" and "venture capital fund". "Seed fund" invests a small amount of free capital to technology start-ups; "venture capital fund" is invested to the businesses relying on the technical achievements [4]. Local governments are expected to optimize the management of funds and offer advisory services to ensure that the venture capital fund can help college students' enterprises grow rapidly and eventually attract venture capital and other financing.

Social financing support mainly comes from venture capital and bank loans. It is especially hard for college students to obtain venture capitals as there is still no mature venture capital market in our country. The traditional bank loan requires high asset guarantees which small businesses can hardly meet. The government is expected to encourage the financing institutions to offer fund to the college students. In this regard, some policies in western counties can be introduced, such as small loans to business start-ups especially these technical enterprises released by special banks, which is guaranteed by the government in the early time and later by the credit system jointly established by the government and colleges. In addition, policies can be issued in favor of the venture capitals to encourage them to invest in the college students businesses [5].

Colleges and universities can provide seed fund for entrepreneurial students. Beijing University of Aeronautics and Astronautics established a annually 3 million venture capital fund to finance those businesses after assessment. Shanghai University of Technology supplies fund to 300 entrepreneurial projects very year. Fudan University unites Fudan University Technology Park and Yangpu Entrepreneurship Center to offer a fund of ten million, and the Yangpu district government promise to add five million in three years[6]. In addition, Universities can also take advantage of the resources to attract corporate donations or investments to set up a venture capital fund. Zhejiang University Technology Innovation Service Platform is designed to utilize the alumni resources and call for entrepreneurship trend and promote the cooperation of scientific and technological achievements transformation and industry study and research. As a part of the platform, the first phase of the "Zhijiang Entrepreneurship Fund" raises 20 million offered by Zhejiang University International Innovation Institute and Insigma Group Co., Ltd. The fund is focusing on support to the start-up of the enterprises with investment objects as the SMEs within five years, with legal personality, and mainly engaged in the research, development, production and service of high-tech products.

\section{B. Middle Stages}

Local labor and social security department is expected to offer business information and free labor qualification training. The Bureau of Industry and Commerce and the 
Tax authorities are supposed to simplify the licensing procedures and relieve all the taxes in the start-up of the businesses [8]. The financial institutes can establish a credit file for the graduates and offer an appropriate amount of loans guaranteed by the government. The national and local government can jointly set up a guarantee fund to provide small loan guarantees and interest subsidies [9]. The personnel department should provide free storage of personnel archives and help deal with the endowment insurance and housing fund.

Entrepreneurial incentive mechanism is an effective measure to protect the enthusiasm of the students to start their own business. For example, graduates starting businesses conforming to the enterprise-oriented requirements can enjoy the registered permanent residence. Citizen treatment shall be given to those nonlocal students. The local government shall implement relevant incentive policies [10]. The effects of implementation shall be focused. The phenomenon of "policies without rules, rules with execution" shall be not allowed. Great efforts shall be done for policy publication and implementation.

\section{Late Stages}

The entrepreneurial environment determines the activity of the entrepreneurial businesses [11]. It is particularly necessary to build a scientific evaluation index system of college student's entrepreneurial environment. The system shall conduct the real-time detection, supervision of entrepreneurial environment, not only with multi-level, multi-dimension, but also from the point of laws and policies and college entrepreneurship education, from which the government can find the key factors which promote or hinder the entrepreneurial activities and thus develop targeted policies to improve the entrepreneurship environment.

The most important factors in the business start-up are the college students and technological achievements. Not all the students are capable of starting businesses and not all the technological achievements are commercially valuable. In order to increase the success rate of business, Entrepreneurial Identification Evaluation System shall be set up to detect the student's qualifications and scientific and technological achievements. Specifically, it shall include the following two parts:

The entrepreneur is the core and the key element of entrepreneurial activity. The quality of the entrepreneur means the unique quality and ability manifested in the business activities. Currently, there is no effective evaluation system of entrepreneurs among Suzhou colleges and universities, which leads to a waste of human resources to a certain extent.

There is a lack of a comprehensive and integrated assessment of scientific and technological achievements for a long time. The effectiveness and market assess of the scientific and technological achievements are not incorporated in the market mechanism. To avoid a big deviation of the industry, study and research activities from the market property, a technological assessment and market broadcast system shall be established [12]. The market analysis of the Technological achievements transfor- mation, together with the prediction of the commercialization, market capacity and market shares can very well inform the enterprises with the information of production efficiency and market development potential and provide references for decision-making and avoid the waste of innovative resources.

\section{ACKNOWLEDGMENT}

This work was supported in part by a grant from National Natural Science Foundation of China (Number: 71002017). This work was supported in part by a grant from Philosophical and Social Science Foundation of University in Jiangsu Province (Number: 2011SJB630052). This work was supported in part by a grant from soft science foundation of Suzhou (Number: SRD201112).

\section{REFERENCES}

[1] Y. W. Tong, "Analysis of the policy for college student's business start-ups," Academic J. Anhui Vocational College Electron. Inf., vol. 3, pp.1-2, 2009.

[2] K. Q. Song, Entrepreneurial Success. Beijing, China: Econ. \&Manage. Press, 2002, pp. 34

[3] Some Opinions on perfect college graduate and trainee. (2011, Dec. 5th). Graduate Career Center of Suzhou, Available: http://www.szbys.com.

[4] R. Y. Xu, "Study on the College Student Entrepreneurship Policy in Zhejiang Province," M.S. thesis, Graduate School of Education, Shanghai Jiao Tong Univ., Shanghai, China, 2010.

[5] H. Tong, "Study on the College Student Entrepreneurship Policy," M.S. thesis, School of Education Science, East China Normal University, 2007.

[6] M. Zhao, "Study on the Entrepreneurship Support System for Shanghai College Students, empirical study of some Shanghai colleges and universities," M.S. thesis, Graduate School of Education, Shanghai Jiao Tong Universities, 2008.

[7] Some Opinions on Improve Vocational Training and Employment Services (2011, 9 8th). China Practice Enterprises Network, Available: http://www.chinapen.org.

[8] J. Wu, "Study on the entrepreneurial Environment for College Students in Zhejiang Provinces," M.S. thesis, Zhejiang University of Technology, 2007.

[9] X. S. Tang, "Study on the College Student Entrepreneurship Policy in Jiangsu Province," M.S. thesis, School of International and Public Affairs, Shanghai Jiao Tong University, 2009.

[10] Z. D. Xu et al., "Study on the Construction of Support System for the College Students Entrepreneurship," Pioneering With Sci. Technol. Monthly, vol.7, pp. 25-27, July 2009.

[11] A. J. Zhou, "Study on the Responsibilities of the Government in the College Students Businesses," Bus. Mod., vol. 4, pp. 61-62, February 2010.

[12] G. Y Wang, "Study on the Commercialization of Research Outputs Bases on the Knowledge Management," Ph.D. Dissertation, School of Management, Tianjin University, 2009.

\section{AUTHORS}

X.Y. Tian, an associate professor, gained her Phd. in 2008 , and now she works in school of economics \& management, Suzhou University of Science and Technology, Suzhou, P.R. China (e-mail: lucy.txy@163.com).

Manuscript received 19 May. Published as re-submitted by the author 13 October 2013. This work was supported in part by the U.S. Department of Commerce under Grant BS123456 